\title{
Analysis of ferruginous bodies in bronchoalveolar lavage from foundry workers
}

\author{
Ronald F Dodson, Michael O'Sullivan, Carolyn J Corn, Joe G N Garcia, James M Stocks, \\ David E Griffith
}

\begin{abstract}
Classical ferruginous bodies in tissue samples are considered to be markers of past exposure to asbestos. Recent studies have shown that the presence of ferruginous bodies in bronchoalveolar lavage (BAL) fluid correlates with past exposure to asbestos and offers a more sensitive reference than occupational history. Lavage samples from five subjects who had worked in foundries were evaluated by light microscopy for the presence of ferruginous bodies and by transmission electron microscopy for both characterisation of the uncoated fibre burden and analysis of the cores of the ferruginous bodies. All samples at lower magnification (light microscopy $(200 \times))$ contained ferruginous bodies that were externally consistent with asbestos bodies. At higher magnification $(400 \times)$, a separate population from this group could be identified by the presence of a thin black ribbon. Transmission electron microscopy of the core materials of ferruginous bodies and comparable uncoated particulates supported the reliability of higher magnification light microscopy for distinguishing most of those nonasbestos cores; however, a population of transparent non-asbestos cored ferruginous bodies were also shown to exist.
\end{abstract}

(British fournal of Industrial Medicine 1993;50:1032-1038)

Department of Cell Biology and Environmental Sciences

R F Dodson, M O'Sullivan, C J Corn

Department of Internal Medicine, The University of Texas Health Center at Tyler, PO Box 2003, Tyler, Texas, 75710 USA

J M Stocks, D E Griffith

Department of Medicine, Indiana University School of Medicine, Indianapolis, Indiana 46202, USA

J G N Garcia
The usefulness of bronchoalveolar lavage (BAL) in $\stackrel{\mathbb{1}}{3}$ supporting the diagnosis of certain occupational of pulmonary diseases has been discussed in several reviews. ${ }^{12}$ Studies have shown that this technique is $\overrightarrow{.}$ useful in confirming past occupational exposure to $\overrightarrow{0}$ asbestos through the presence of ferruginous $\underset{N}{\mathbb{N}}$ bodies in the BAL fluid. ${ }^{3-5}$ De Vuyst and colleagues $ㅇ$ have further shown a correlation between the concentration of asbestos bodies in BAL fluid and $z$ fibre burden in the lung. ${ }^{6}$ Two other reports used $?$ analytical electron microscopy to confirm that the $\frac{\Phi}{3}$ cores of ferruginous bodies in BAL fluids were $\bar{\nabla}$ asbestos fibres. ${ }^{78}$ All of these studies included at least one group of subjects having known $\& \vec{\theta}$ suspected occupational exposure to asbestos. Th use of light microscopy for defining the number $\frac{0}{0}$. ferruginous bodies and the assumption that these are asbestos bodies are supported by the arguments: (1) occupational exposure to asbestos is a known stimulus for ferruginous body formation; $\mathbb{D}$ (2) Churg and Green have stated that "nonasbestos-containing bodies are easily separated $\frac{0}{3}$ from true asbestos bodies with a light micro- $\frac{}{J}$ scope." ${ }^{9}$ The criteria used by Churg and Green ${ }^{9}$ and De Vuyst $e t a l^{6}$ for equating ferruginous bodies with asbestos bodies include being formed on $a \stackrel{\Phi}{\$}$ clear, often straight, core, and having a regular or $?$ segmented, yellow to brown ferroprotein coating.

In further support of this conclusion, asbestos has been shown by analytical electron microscopy to comprise the core material in samples from the

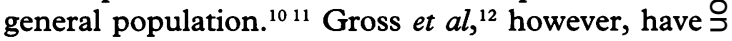
reported that transparent non-asbestos fibres are $>$ capable of producing ferruginous bodies in experimental animal models. Appreciable numbers of $N$ such uncoated non-asbestos fibres ${ }^{1314}$ have been reported in human lungs and thus offer the poten- $N$ tial for various types of cores.

The foundry workers in the present report hado been exposed to a mixed dust environment that hase been characterised as potentially containing fibrous $\Phi$ (asbestos and non-asbestos) and non-fibrous $\stackrel{?}{+}$ dusts. ${ }^{15-17}$ The BAL fluids from five subjects with 0 such exposures were referred for laboratory assess- $\frac{0}{\mathbb{D}}$

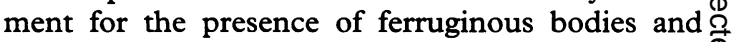
characterisation of the uncoated fibre burden. 


\section{Patients and methods}

Bronchoalveolar lavage fluid was collected as a part of a diagnostic evaluation from five men who had a history of working from 20 to 31 years in foundries and iron reclamation plants. All were from nonurban areas of east Texas and their ages ranged from 60 to 77 (average 66) years. The group contained two non-smokers and three former smokers.

Fibreoptic bronchoscopy was used to collect samples. A total of $100 \mathrm{ml}$ saline was injected into selected areas (right middle lobe or lingula) of the lung in $20 \mathrm{ml}$ aliquots. The recovered fluid ranged from $19 \mathrm{ml}$ to $83 \mathrm{ml}$ (average $47 \mathrm{ml}$ ). A small aliquot $(<0.1 \mathrm{ml})$ was taken for determination of white cell and differential cell counts. The percentage of phagocytes was obtained by combining the macrophage, neutrophil, and eosinophil percentages. This percentage of phagocytes, which ranged from $84 \%$ to $99 \%$ (average $89.4 \%$ ), was then multiplied by the white cell count. The remaining BAL fluid was centrifuged at $700 \mathrm{~g}$ for 10 minutes to concentrate the material. The pellet was resuspended in a known volume (2 to $10 \mathrm{ml}$ ) of $3 \%$ phosphate buffered glutaraldehyde fixative, $(\mathrm{pH}$ $7 \cdot 3,0 \cdot 1 \mathrm{M})$. The white cell count for the fixed BAL fluid ranged from 270000 to 1050000 (average 667800 ) white cells $/ \mathrm{ml}$ and the phagocytes ranged from 226800 to 1039500 (average 613794 ) phagocytes $/ \mathrm{ml}$.

Samples for analysis were prepared with the modified bleach digestion procedure of Williams et al. ${ }^{18}$ All reagents and distilled water were prefiltered $(0.2 \mu \mathrm{m}$ polycarbonate filter, Nuclepore). Reagent blanks were prepared to determine background contamination. Digested BAL fluid material was collected on either $0.2 \mu \mathrm{m}$ polycarbonate (Nuclepore) or $0.22 \mu \mathrm{m}$ mixed cellulose ester (Millipore) filters. The amount of glutaraldehyde fixed digested material collected on the polycarbonate filters ranged from 1.0 to 2.5 (average 1.5 ) $\mathrm{ml}$ and from 340000 to 1039500 (average 791 394) phagocytes, whereas the amount filtered for the mixed cellulose ester filters ranged from 0.5 to 3.0 (average 1.55 ) $\mathrm{ml}$ and from 319200 to 1479000 (average 740833 ) phagocytes. A ratio of $1 \mathrm{ml}$ of glutaraldehyde fixed BAL fluid to $8-10 \mathrm{ml}$ sodium hypochlorite bleach $(9 \cdot 2 \%$ Wright's laundry bleach) was used for the digestions. The filters were treated sequentially with $4 \%$ potassium permanganate, $8 \%$ oxalic acid, $9 \cdot 2 \%$ bleach, and $8 \%$ oxalic acid. ${ }^{18}$ Each addition was followed by a water rinse. Filters were air dried, mounted on glass slides, and stored in Petri dishes.

\section{LIGHT MICROSCOPY}

One quarter of each mixed cellulose ester filter was collapsed in acetone vapour, placed under a cover slip, and reviewed at $200 \times$ to $400 \times$ with an $\mathrm{AO}$ MicroStar microscope. All ferruginous bodies were counted and categorised based on external morphology and, where possible, on appearance of the core material.

The general term ferruginous body, denotes a golden brown ferrocoated structure ${ }^{11} 1219$ and in the initial scan of the filter, various forms of ferruginous bodies were seen in each subject.

To differentiate the separate forms, a classification system of four categories was used. The first category (type A) consisted of elongated reddish or golden brown structures with beaded or segmented morphology and contained a transparent fibrous core. An additional group of similar structures was totally coated. Both of these beaded forms were morphologically identical to classical asbestos bodies as defined by light microscopy. ${ }^{911} 1920$

The second category (type B) was identical to the type A structures in external morphology, but at $400 \times$ magnification, a thin black filament was evident as the central core.

The type $C$ ferruginous bodies were also formed on a black core. This core was rectangular or rod like in appearance rather than a thin central filament. The external morphology was consistent with the beaded form of the type $A$ and $B$ ferruginous bodies.

The final form (type D) was covered with a ferruginous coating and was clearly not formed on a fibrous or elongated core, but rather on black or grey particles of various shapes.

All the types of ferruginous bodies had a golden or reddish brown coat. A summary of the ferruginous body classification by light microscopy is: type A-clear core (classic ferruginous body); type B-Thin black filament core (seen at $400 \times$ ); type C-Black, thick with elongated core; type D-Odd shaped ferruginous body with gray or black core.

\section{ELECTRON MICROSCOPY}

Each polycarbonate filter was carbon coated at $4 \times 10^{-6}$ Torr in a Denton 502A vacuum evaporator for transmission electron microscopy and sections were mounted in 100/200 mesh folding copper grids. The filter matrix was dissolved in chloroform with a modified Jaffe-wick procedure, thereby entrapping fibres and ferruginous bodies in the remaining carbon film. For scanning electron microscopy, filter sections were mounted on carbon studs with colloidal graphite. The sections were coated with gold in an Emtech $\mathrm{K} 550$ for four minutes at $7.5 \times 10^{-3}$ Torr argon. Transmission and scanning electron microscopy preparations were evaluated in a JEOL $1200 \mathrm{EX}$ interfaced to a TN-5500 Series II $x$ ray energy dispersive analyser. $x$ Ray energy dispersive spectrometry (XEDS) is capable of digital beam $x$ ray mapping of the- 
Table 1 Ligand microscopy data

\begin{tabular}{|c|c|c|c|c|c|c|c|c|c|c|}
\hline \multirow[b]{2}{*}{ Smoking history } & \multicolumn{5}{|c|}{ Phagocytes/ferruginous body } & \multicolumn{5}{|c|}{ Ferruginous bodies $/ m l$} \\
\hline & Type A & Type B & Type C & Type D & $\begin{array}{l}\text { Limit of } \\
\text { detection }\end{array}$ & Type A & Type B & Type C & Type D & $\begin{array}{l}\text { Limit of } \\
\text { detection }\end{array}$ \\
\hline $\begin{array}{l}\text { Patient } 1 \\
\quad \text { former smoker }\end{array}$ & 3325 & 1628 & 3469 & 927 & $>79800$ & 96 & 196 & 92 & 344 & $<4$ \\
\hline $\begin{array}{l}\text { Patient } 2 \\
\quad \text { former smoker }\end{array}$ & 660 & 192 & 168 & 78 & $>194906$ & 1573 & 5408 & 6181 & 13242 & $<5$ \\
\hline $\begin{array}{l}\text { Patient } 3 \\
\text { non-smoker }\end{array}$ & 3013 & 111483 & 1570 & 218 & $>111483$ & 296 & 8 & 568 & 4080 & $<8$ \\
\hline $\begin{array}{l}\text { Patient } 4 \\
\quad \text { former smoker }\end{array}$ & 2501 & 14175 & 5154 & 4361 & $>170100$ & 90 & 16 & 44 & 52 & $<1$ \\
\hline $\begin{array}{l}\text { Patient } 5 \\
\text { non-smoker }\end{array}$ & 17607 & 61625 & 8803 & 370 & $>369750$ & 34 & 10 & 67 & 1600 & $<2$ \\
\hline
\end{tabular}

Type $A=$ classic clear core; Type $B=$ thin black filament; Type $C=$ thick black elongated; Type $D=$ odd shape.

elemental components that have a greater atomic number than neon. This technique was applied in assessing the core of the totally coated ferruginous bodies.

Two grids from each patient were scanned at $10000 \times$ and $20000 \times$ for the uncoated fibre burden. All uncoated fibres with substantially parallel sides, a length/width ratio $\geqslant 3: 1$, and a length of $\geqslant 0.5 \mu \mathrm{m}$ were counted, as well as analysed by both XEDS and selected area diffraction. Ferruginous body cores were analysed when possible.

Fibres and ferruginous bodies within each BAL fluid samples were categorised and reported as (1) fibres or ferruginous bodies $/ \mathrm{ml}$ of glutaraldehyde fixed BAL fluid and (2) phagocytes/fibre or ferruginous body.

\section{Results}

Table 1 shows a summary of the light microscopy data from the study. The light microscopy confirmed the presence of transparent cored ferruginous bodies (type A) consistent with asbestos bodies in all five patients (fig 1). ${ }^{21}$ The percentage

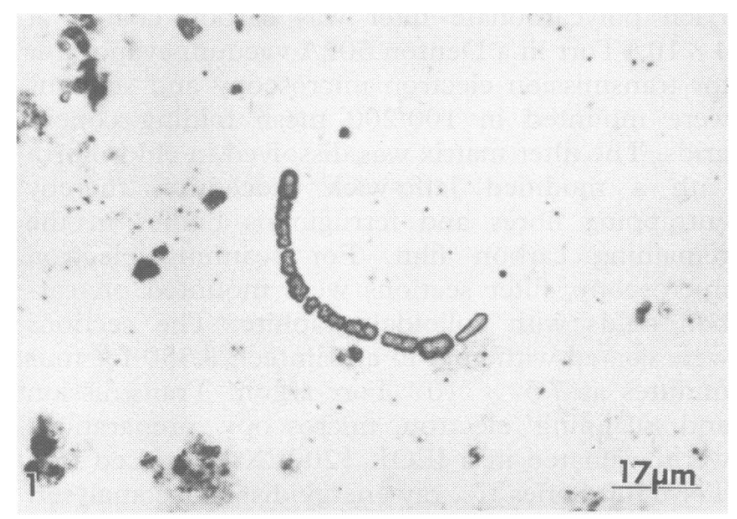

Figure 1 Typical clear cored ferruginous body that was classified as type $A$. Originally $\times 1200$. of type $\mathrm{A}$ or classical ferruginous bodies comprised $12 \%-60 \%$ of the total ferruginous body burden in the lavage samples from the patients. The type $B$ and $\mathrm{C}$ forms of ferruginous bodies were distinguished from the type A by their visible black cores (fig 2). Similar ferruginous bodies have been referred to previously by Churg et al as carbon bodies. ${ }^{11}$ As noted in the definitions within the methods section, there were physical differences in core structure. Those classified as the B form contained a thin filament that was either difficult or impossible to see at lower magnification, whereas the $\mathbb{8}$ structures were thick black rods or plates and easil detected at $100 \times$ magnification. The $B$ and forms combined accounted for over $65 \%$ of the total ferruginous bodies as formed on elongated core material in four of the five patients and $40 \%$ in the fifth patient (table 2).

The pleomorphic particulates that formed the cores of the $\mathrm{D}$ form consisted of particulates of various colours ranging from pale yellow to grey and black tones. This form of coated material constituted the highest number of ferruginous entities in three of the five patients. None of these were

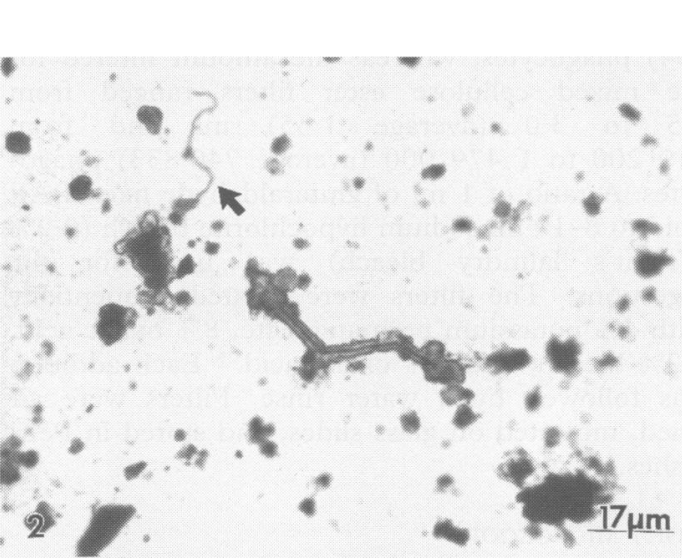

Figure 2 Both type $B$ and type $D$ ferruginous bodies, arrow points to an uncoated black filament. Originally $\times 1200$. 
Table 2 Comparison of fibrous cored ferruginous bodies by type

\begin{tabular}{lllll}
\hline Patient & $\begin{array}{l}\text { Type } A \ddagger \\
(\%)\end{array}$ & $\begin{array}{l}\text { Type } B+C \dagger \\
(\%)\end{array}$ & $\begin{array}{l}\text { Type } B \dagger \\
(\%)\end{array}$ & $\begin{array}{l}\text { Type } C+ \\
(\%)\end{array}$ \\
\hline 1 & 25 & 75 & 51 & 24 \\
2 & 12 & 88 & 41 & 47 \\
3 & 34 & 66 & 1 & 65 \\
4 & 60 & 40 & 11 & 29 \\
5 & 31 & 69 & 9 & 60 \\
\hline
\end{tabular}

$\ddagger$ Asbestos; †Non-asbestos.
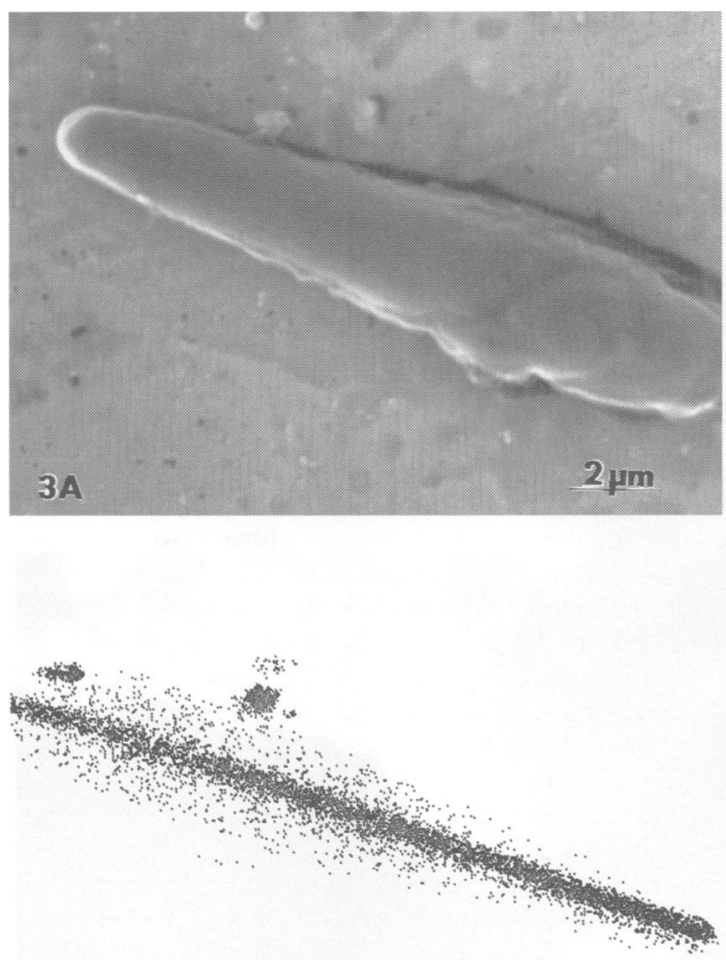

3B

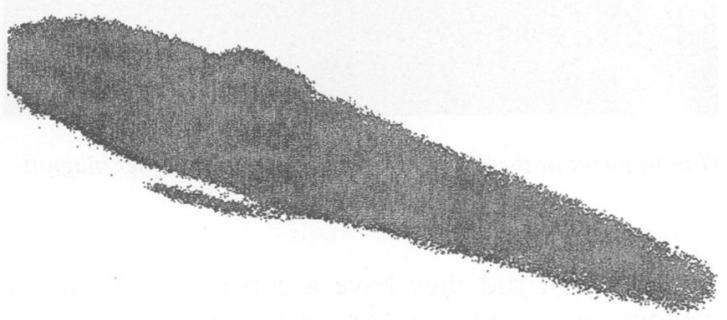

3C

Figure 3(A) Scanning electron micrograph containing a totally coated head region of an asbestos body. Originally $\times 9600$. (B) Elemental $x$ ray map from the asbestos body in $(A)$ indicating that silicon is detectable through the iron coated areas. (C) The iron $x$ ray map of the same field as in (B). fibrous and therefore would not be confused with the $B$ and $C$ forms. The ferruginous coats of the D form of ferruginous body were often extensive. The coating material often formed terminal blebs that extended from the central region, but the extensions did not seen to contain core material.

\section{TRANSMISSION ELECTRON MICROSCOPY}

Fifty two apparently classical ferruginous bodies (type A by light microscopy) were analysed to determine core composition. Eight were formed on amosite asbestos, two were formed on fibreglass, and six were formed on thin elongated sheet silicates. Thirty seven of these bodies were totally coated and only iron peaks were obtainable by XEDS. This implies that the central fibre was either iron or carbon, or shielded sufficiently by the coating to prevent peak production. Our XEDS analysis suggests that the core material was often of carbon composition (type B filaments), as no energy peaks except iron were produced. This contrasts with the generation of peaks of silicon from totally coated asbestos bodies (figs 3(A), 3(B), and 3(C).

The exposed cores of sixty type B ferruginous bodies were analysed. The exposed black filament in type $B$ ferruginous bodies (figs $4(A)$ and $4(B)$ ) did not give peaks by $x$ ray energy analysis and was considered to be an amorphous organic material, as was the central area of the type $C$ form. By electron microscopy, the distinction between the type B and $\mathrm{C}$ forms at the light microscopy level was based only on thickness of the core material. The analysis of cores from nine of the $C$ types gave the same information as the analysis of the cores of the type $B$ forms.

The type $\mathrm{D}$ ferruginous bodies could not be confused by light or electron microscopy with ferruginous bodies formed on fibrous material. The analysis of the core material of 140 such structures was confirmed to be mixed dust (fig 5). These included carbon material, (no XEDS peaks above neon) silica, and titanium, as well as various alumina silicates and mixed silicates.

Uncoated chrysotile or amosite asbestos fibres were found in the lavage samples from four of the five patients whereas fibreglass fibres were found in material from two patients. Four of the patients were found to have amorphic fibres as determined by selected area diffraction and did not yield detectable elements when analysed by XEDS (fig 6). These fibres were considered to be the equivalent of the cores of the $B$ and $C$ form of ferruginous body and comparable by XEDS to the carbon cores described by Churg and Warnock. ${ }^{19}$ Each of the samples also had other uncoated fibres that were found to be silicon, titanium, iron, or various aluminum silicates by XEDS analysis (table 3). 


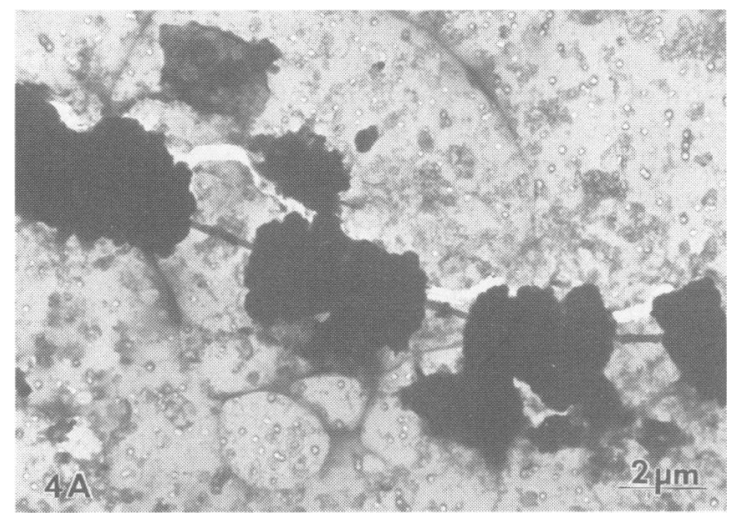

variation in orientation of coating material, many of these are not evident at lower magnification. This may seem like a trivial issue, easily overcome by simply shifting to high dry objective; however, there are numerous studies in which counts of ferruginous bodies are made at $100 \times$. As these bodies are externally identical to asbestos bodies, such a count would have likely not differentiated these non-asbestos types. Also, those formed on sheet sil- की icates and fibreglass were similar to asbestos bodies $\overrightarrow{0}$ in external appearance. Compounding the problem of differentiating the cores of sheet silicates was the fact that the particles were neither noticeably

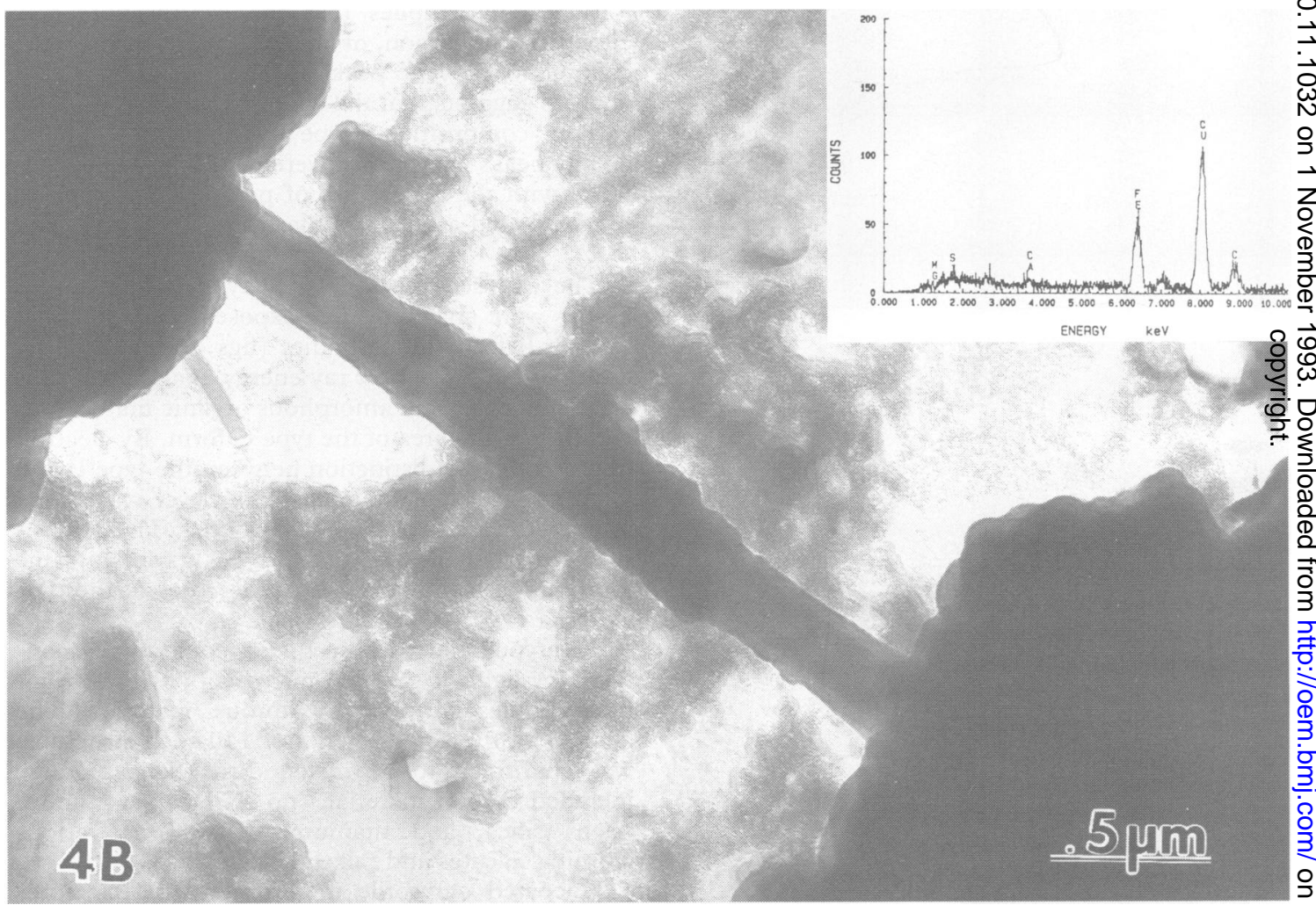

Figure 4(A) Type B ferruginous body. Originally $\times 8600$. (B) Thin filament in the ferruginous body of $(A)$ at higher magnification. Inset shows XEDS of filament. Originally $\times 58000$.

\section{Discussion}

The BAL material from the foundry workers contained four types of iron coated structures. Our data are generally in agreement with Churg's' ${ }^{21}$ conclusion that non-asbestos ferruginous bodies can be detected by light microscopy. We would, however, offer the qualifier that those formed on thin filaments (type B) often require higher magnification $(400 \times)$ to resolve the core material. Due to the 


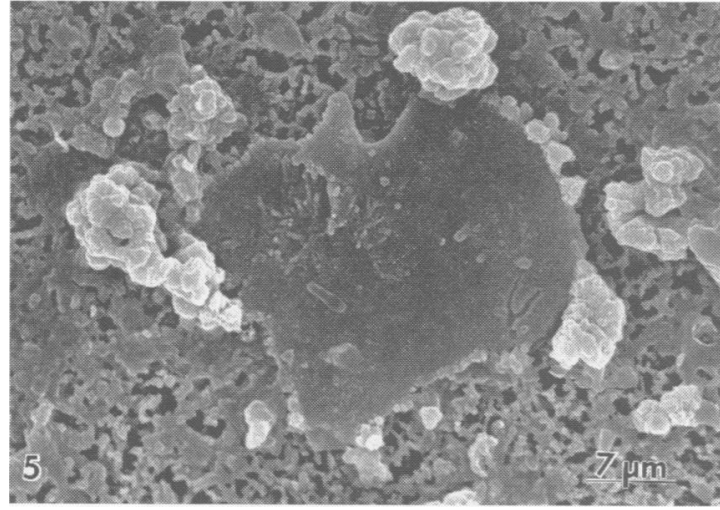

Figure 5 Type D classification illustrates that the ferruginous material was formed on a central plate. No peaks, other than iron, were obtained by XEDS of the material. Originally $\times 2900$. same structures seen in various orientations in tissue sections may not be as easily interpreted.

The presence of an iron coat in any form may increase the cytotoxic potential of the core particulate. Although the process of coating seems to physically isolate particulates from the tissue environment, Lund et al found when comparing single strand breaks in a DNA model that there was a greater reactivity associated with coated asbestos compared with equivalent concentrations of uncoated asbestos (unpublished data).

Our present study of lavage samples from foundry workers confirmed the presence of classical ferruginous bodies as reported in previous studies of tissue samples, ${ }^{22}{ }^{23}$ and lavage material. ${ }^{24}$ The data from the present study likewise confirm an exposure to mixed dusts that included both fibrous and non-fibrous forms that were capable of stimulating the formation of ferruginous bodies. Those ferruginous bodies formed on non-asbestos fibres can greatly exceed the numbers of classical asbestos bodies in such exposures.

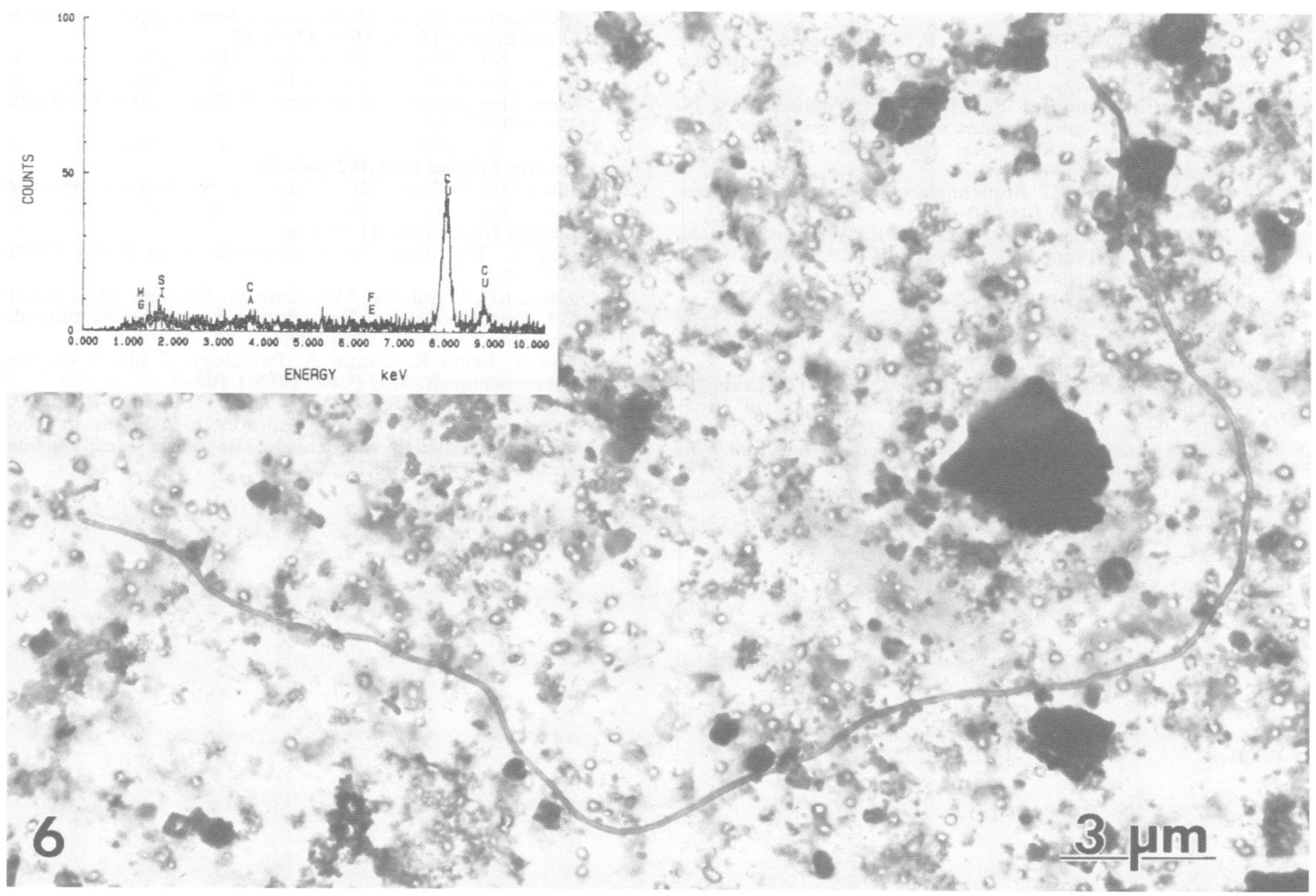

Figure 6 Only a background peak of copper is generated on this XEDS (inset) of an uncoated fibre that is equivalent to the core material in the type $B$ ferruginous body, originally $\times 8000$. 
Table 3 Other uncoated fibres, identified by $x$ ray energy dispersive spectrometry

\begin{tabular}{|c|c|c|c|c|c|c|c|c|c|c|}
\hline \multirow[b]{2}{*}{ Patient } & \multicolumn{5}{|l|}{ Fibres/ml } & \multicolumn{5}{|c|}{ Phagocytes/fibre } \\
\hline & Chrysotile & Amosite & Glass & Organic & Other* & Chrysotile & Amosite & Glass & Organic & Other* \\
\hline $\begin{array}{l}\text { Patient } 1 \\
\text { Patient } 2 \\
\text { Patient } 3 \\
\text { Patient } 4 \\
\text { Patient } 5\end{array}$ & $\begin{array}{l}\text { ND } \\
1256 \\
3832 \\
838 \\
\text { ND }\end{array}$ & $\begin{array}{l}50 \\
1005 \\
N D \\
N D \\
N D\end{array}$ & $\begin{array}{l}\text { ND } \\
\text { ND } \\
377 \\
1815 \\
\text { ND }\end{array}$ & $\begin{array}{c}251 \\
1570 \\
5026 \\
\mathrm{ND} \\
837\end{array}$ & $\begin{array}{r}377 \\
5025 \\
6596 \\
964 \\
3350\end{array}$ & $\begin{array}{c}\text { ND } \\
827 \\
3633 \\
271 \\
\text { ND }\end{array}$ & $\begin{array}{l}6352 \\
1034 \\
\text { ND } \\
\text { ND } \\
\text { ND }\end{array}$ & $\begin{array}{c}\text { ND } \\
\text { ND } \\
2382 \\
248 \\
\text { ND }\end{array}$ & $\begin{array}{c}1270 \\
690 \\
178 \\
\text { ND } \\
706\end{array}$ & $\begin{array}{l}953 \\
207 \\
188 \\
519 \\
176\end{array}$ \\
\hline
\end{tabular}

$\mathrm{ND}=$ none detected; ${ }^{\star}$ Other $=\mathrm{Si}, \mathrm{Ti}, \mathrm{Fe}, \mathrm{Al}, \mathrm{AlSi}, \mathrm{AlSiCa}, \mathrm{AlSiFe}, \mathrm{SiFe}$.

We thank Ms Carolyn Tuley for typing the manuscript, and Ms Benji Hawkins and Mr James Brown for technical support.

Requests for reprints to: Ronald $\mathrm{F}$ Dodson $\mathrm{PhD}$, Professor and Chairman, Department of Cell Biology and Environmental Sciences, The University of Texas Health Center at Tyler, Post Office Box 2003, Tyler, TX 75710, USA.

1 Crystal RG, Reynolds HY, Kalica AR. Bronchoalveolar lavage. The report of an international conference. Chest 1986;90:122-31.

2 Begin RO. Bronchoalveolar lavage in the pneumoconioses. Chest 1988;94:454.

3 De Vuyst P, Jedwab J, Dumortier P, Vandermoten G, Vande Weyer R, Yernault JC. Asbestos bodies in bronchoalveolar lavage. Am Rev Respir Dis 1982;126:972-6.

4 De Vuyst $P$, Dumortier P, Moulin E, Yourassowsky N, Yernault JC. Diagnostic value of asbestos bodies in bronchoalveolar lavage fluid. Am Rev Respir Dis 1987;136: 1219-24.

5 Rebuck AS, Braude AC. Bronchoalveolar lavage in asbestosis. Arch Intern Med 1983;143:950-2.

6 De Vuyst P, Dumortier P, Moulin E, Yourassowsky N, Roomans P, de Francquen P, Yernault JC. Asbestos bodies in bronchoalveolar lavage reflect lung asbestos body concentration. Eur Respir f 1988;1:362-7.

7 Barbers RG, Abraham JL. Asbestosis occurring after brief inhalational exposure: usefulness of bronchoalveolar lavage in diagnosis. $\mathrm{Br} \mathcal{F}$ Ind $\mathrm{Med} 1989 ; 46: 106-10$.

8 Dodson RF, Garcia JGN, O'Sullivan M, Corn CJ, Levin JL, Griffith DE, Kronenberg RS. The usefulness of bronchoalveolar lavage in identifying past occupational exposure to asbestos: a light and electron microscopy study. $A m \mathcal{F}$ Ind Med 1991;19:619-28.

9 Churg A, Green FHY. Pathology of occupational lung disease. New York: Igaku-Shoin, 1987;213-77.
10 Churg A, Warnock ML. Analysis of the cores of ferruginous (asbestos) bodies from the general population. I. Patients with and without lung cancer. Lab Invest 1977;37:280-6.

11 Churg A, Warnock ML, Green N. Analysis of the cores of ferruginous (asbestos) bodies from the general population. $L a b$ Invest 1979;40:31-8.

12 Gross P, deTreville RTP, Cralley LJ, Davis JMG. Pulmonary ferruginous bodies. Arch Pathol 1968;85:539-46.

13 Churg A, Wood P. Observations on the distribution of asbestos fibers in human lungs. Environ Res 1983;31: 374-80.

14 Dodson RF, Williams MG, O'Sullivan MF, Corn CJ, Greenberg SD, Hurst GA. A comparison of the ferruginous body and uncoated fiber content in the lungs of forme asbestos workers. Am Rev Respir Dis 1985;132:143-7.

15 Kleinfeld M, Messite J, Shapiro J, Kooyman O, Levin E. A clinical, roentgenological, and physiological study of magnetite workers. Arch Environ Health 1968;16:392-7.

16 Kalliomaki P-L, Korhonen O, Mattsson T, Sortti V, Vaaranen V, Kalliomaki K, Koponen M. Lung contamination among foundry workers. Int Arch Occup Environ Health 1979;43: 85-91.

17 Koponen M, Gustafsson T, Kalliomaki K, Kalliomaki P-IO Moilanen M, Pyy L. Dusts in a steel-making plant. Int Arck Occup Environ Health 1980;47:35-45.

18 Williams MG, Dodson RF, Corn C, Hurst GA. A procedure for the isolation of amosite asbestos and ferruginous bodies from lung tissue and sputum. $\mathcal{F}$ Toxicol Environ Health 1982;10:627-38.

19 Churg A, Warnock ML. Asbestos and other ferruginous bodies. Am F Pathol 1981;102:447-56.

20 Dodson RF, Williams MG, Hurst GA. Method for removing the ferruginous coating from asbestos bodies. F Toxicol Environ Health 1983;11:959-66.

21 Churg A. The diagnosis of asbestosis. Hum Pathol 1989; 20:97-9.

22 Dodson RF, O'Sullivan MF, Corn C, Williams MG, Hurst GA. Ferruginous body formation on a nonasbestos mineral. Arch Pathol Lab Med 1985;109:849-52.

23 Masse S, Begin R, Cantin A. Pathology of silicon carbide pneumoconiosis. Mod Pathol 1988;1:104-8.

24 Corhay J-L, Delavignette J-P, Bury T, Saint-Remy $P$ Radermecker M-F. Occult exposure to asbestos in steel workers revealed by bronchoalveolar lavage. Arch Environ Health 1990;45:278-82.

Accepted 18 January 1993 